\title{
Jobs, Crime, Proximity and Boats: Explaining Australian Public Attitudes to
}

\author{
Immigrant Numbers
}

\begin{abstract}
Despite the importance of immigration to Australia, there is little systematic research on the causes of support among Australian citizens for increased, stable or decreased immigration. This paper advances our understanding of Australian public attitudes to immigration levels in the light of the established international literature on public opinion and immigration. Using 2013 Australian Electoral Study (AES) data, we show that, as in other countries, Australian citizens' attitudes to immigrant numbers are partly driven by a combination of sociotropic economic considerations and perceptions of the socio-cultural impact of immigrants. In addition, we argue that political mobilisation has an impact on attitudes toward immigration that has not received sufficient attention. We demonstrate that citizens who accepted the Coalition's rhetoric on asylum seeker arrivals were more likely to want overall immigrant numbers reduced. Finally, we combine the individual level AES data with electoral district level data to test the impact of contact with immigrants on attitudes to immigrant numbers. Australians living in electoral districts with higher percentages of nonwhite immigrants are more likely to want lower immigrant numbers than those living in districts with fewer non-white immigrants.
\end{abstract}

\section{Introduction}

Despite the long-term importance of immigration to Australia and the some highly contentious Australian public debates over immigration in recent decades (Markus et al. 2009), remarkably little systematic research exists on the causes of support for increased, stable or decreased immigration levels among Australian citizens. A number of studies over the past fifty years have analysed the general politics of Australian immigration policy (see, for example, Jupp 1966; Jupp 2007). Other studies have explored the effects of attitudes to immigration on electoral behaviour, particularly since the emergence of the One Nation Party (see, for example, Goot and Watson 2001; Ratcliff 2014). Researchers have also often traced overall movements in public attitudes toward immigration levels, demonstrating large fluctuations in public opinion. Support for reducing the migrant intake has ranged widely since the 1970 s, reaching over 70 percent and falling below 30 percent (Markus 2016). The direction, size and 
significance of these shifts in public support have been contentious. While some of the observed shifts are likely to have been due to variations in question wordings across different surveys, they also reflect real shifts in public attitudes (Markus et al. 2009; Betts 2010; Goot and Watson 2011; Markus 2014,2016). Despite the widely acknowledged successes of Australia's immigration program since World War Two, the Australian public's support for immigration levels has never been guaranteed.

While shifts in public support for immigration levels have received considerable academic attention, the factors underlying public support or opposition to immigration flows have been the subject of far less inquiry. Researchers have often been content to speculate in an ad hoc way about possible causal factors, such as changes to government policy (Betts 2002), or to focus their attention on bivariate correlations, such as the positive relationship between unemployment levels and support for reduced immigration (McAllister 1993b, 2011 ; Goot 2000; Markus et al. 2009; Markus 2016). While these explanations provide good starting points for analysis, they do not consider the possible effects of other variables. Although some works have employed multivariate explanations, they have restricted their modelling to demographic variables (Markus and Dharmalingam 2007), demographic variables and vote choice (Goot and Watson 2011: 43-51) and consideration of national identity and 'nativism' (Goot and Watson 2005; 2010).

These studies make useful contributions but as Goot and Watson's fullest model indicates (2005), they do not tell the full story about attitudes to immigration levels. In fact, the Australian research has been conducted with very little reference to international literature on attitudes to immigration that usually includes consideration of economic, cultural, contact and informational factors. This paper is an attempt to advance our understanding of Australian public attitudes to immigration levels in the light of the established literature on public opinion and immigration. 
This paper makes three main contributions to our understanding of Australian popular attitudes to immigration levels:

1. It applies a set of established hypotheses drawn from the international literature to the Australian case.

2. It advances previous attempts to explain Australian support for immigration levels by including a range of attitudinal, demographic, geographic and political variables.

3. It highlights the impact of political mobilisation on attitudes toward immigration by demonstrating the effect on support for reducing immigrant numbers of the Coalition's repeated claim that asylum seeker arrivals meant the Labor Government had lost control of the number of people entering Australia's borders.

We advance ten hypotheses--four dealing with economic factors, four with socio-cultural factors and two with political factors - and test these using a dataset that combines nationwide individual survey data from the 2013 Australian Election Study (AES) with electoral district level data drawn from the Australian Bureau of Statistics (Bean et al. 2014; Australian Bureau of Statistics 2013). The electoral district data allow us to contribute to the inconclusive literature on the effects of contact with visibly different immigrants on attitudes to immigration (see Blake 2003). We do this by testing, for the first time, the impact of the ethnic composition of local immigrant communities on Australian citizens' attitudes toward immigration levels. We find that Australians living in electoral districts with higher percentages of non-white immigrants are more likely to want to decrease the number of immigrants than those living in electoral districts with fewer non-white immigrants. The other findings largely confirm those of earlier studies, suggesting that Australian attitudes to immigrant numbers are partly driven by a combination of sociotropic economic considerations and perceptions of the socio-cultural impact of immigrants. 
One of our key arguments is that political mobilisation plays an important role, alongside economic and cultural factors, in shaping attitudes to immigration levels. This argument has not been tested in previous research in Australia. Our main reason for focusing on data from 2013 is that the 2013 federal election represented the peak of a heated debate between Australia's political leaders in which immigration policy was largely reduced to dealing with asylum seekers attempting to reach the country by boat (see below). We find that voters who agreed with the Liberal and National Coalition's policy of turning asylum seeker boats away from Australia were more likely to want reduced immigration levels than voters who rejected the policy.

In the rest of the paper we first set out the ten hypotheses, drawing on previous relevant literature, explain the data sources and methods, and present the results and its discussion. The concluding section summarises the key findings and suggests areas for future research.

\section{Previous explanations of public opinion about immigration levels}

The academic literature on the determinants of public opinion on immigration has been traditionally organized into two sets of arguments: those focused on different economic dimensions and those considering socio-cultural factors. Drawing in the comparative literature, we identify eight economic and socio-cultural hypotheses, and also propose two new political factors that, to our knowledge, have not been considered when accounting for public opinion on immigration levels.

\section{Economic factors}


The importance of economic factors is widely recognized in the international literature on public attitudes toward immigrants, although considerable debate remains about it impact and importance since we cannot cover all the economic hypotheses offered, instead, we focus on the mainstream explanations.

First, the resource hypothesis concerns perceived impacts of immigration levels on the individual and those close to her or him. It posits that 'people who are experiencing financial stress will be more likely than the well-off to fear the implications of immigration' (Citrin et al. 1997, 860). Hence, we should expect more negative attitudes towards immigrants among those who are currently experiencing difficult economic situations. There has been mixed evidence for this hypothesis in the North American case (Citrin et al. 1990; 1997; Espenshade and Calhoun 1993). Previous Australian research shows that people finding it 'difficult to get by' are more likely to want immigration reduced (Goot and Watson 2005; 2010). We test the resources hypothesis in the following form:

H1: all other things being equal, those who have experienced a decline in their household's financial situation will want to decrease the number of immigrants.

A second explanation, known as the job threat hypothesis (Citrin et al. 1997), suggests that native workers facing higher competition in the labor market due to the presence of immigrants of similar skill levels will feel more negatively toward immigrants and want to reduce immigrant numbers (Citrin et al. 1997; Facchini and Mayda 2006). Support for this hypothesis is mixed. On the one hand, a cross-national study by Mayda found that 'labor market concerns ... play a key and robust role in preference formation over immigration policy’ $(2006,511)$. On the other hand, Hainmueller and Hiscox $(2007 ; 2010)$ found no evidence for the job threat hypothesis in Europe or the United States. A slightly different approach in the literature suggests that individuals' attitudes are primarily affected by perceptions of how immigration affects the broader employment environment, rather than their individual job 
prospects (see, for example, Citrin et al. 1997; Sides and Citrin 2007). These sorts of sociotropic perceptions have commonly been advanced to explain Australian attitudes to immigration. Support for the White Australia policy used to exclude 'non-white' foreign workers from the 1880s to the 1960s was often justified in terms of fears of employment competition, rather than outright racism (Jupp 1995; 2007). We test the sociotropic version of the job threat hypothesis:

$\mathrm{H} 2$ : all other things being equal, those thinking that immigrants take jobs away from Australian-born workers will want to decrease the number of immigrants.

The third economic explanation focuses on perceptions of economic change known as the 'pessimism hypothesis': 'the belief that one is on a downward economic trajectory increases the tendency to view immigration as resulting in tangible costs to oneself and enhances restrictionist sentiment' (Citrin et al. 1997, 860-861). This individual perception has its sociotropic counterpart in perceptions of the 'overall economic health of the country' (Sides and Citrin 2007, 479). Evidence supports this hypothesis for the United States, Canada and Europe (Citrin et al. 1997; Sides and Citrin 2007; Wilkes et al. 2008). We test the explanation as follows:

H3: all other things being equal, those satisfied (dissatisfied) with the national economic situation will be more likely to want to increase (decrease) the number of immigrants.

The final economic hypothesis takes a broad 'res publica' approach, suggesting that general assessments about the economic impact of immigration over time will influence opinions about immigrant numbers at any particular time. Given its historical reliance on immigration to meet labour needs and market growth (Markus et al. 2009), the argument that immigration is generally good for the economy should find fertile ground in Australia. Therefore: 
H4: all other things being equal, those who think that immigrants are generally positive (negative) for Australia's economy will want to increase (decrease) the number of immigrants.

\section{Socio-Cultural factors}

'Socio-cultural' or 'identity' factors, such as 'racism, xenophobia and milder forms of nationalist sentiment such as social norms or cultural preferences' (O'Rourke and Sinnott, 2005: 839) provide a second set of explanations in international scholarship. At its core lies 'the prominence of the differences' between immigrants and the native-born (Sniderman et al. 2004, 36). Previous studies of public opinion on immigrant levels have often been framed as a contest between the strength of economic and socio-cultural explanations (Sniderman et al. 2004; Mayda 2006; Hainmeuller and Hiscox 2010). We believe that there is enough evidence for the impact of both economic and socio-cultural factors in those studies to include both in our models.

In Australia, socio-cultural dynamics are most likely to play out in the visible differences between the 'white' anglo-celtic settler majority and the increasing numbers of 'non-white' immigrants from Asia, the Middle East and Africa (Perkins 2007). Evidence from the late 1980s shows that Australians were more welcoming of European than Middle Eastern or Asian immigrants (Smith 2001). Previous studies also suggest that where the dominant white group sees immigrants as a threat, its members are likely to want immigration reduced (Goot and Watson 2010). On the other hand, where members of the dominant white group see the arrival of 'non-white' immigrants from other cultures as enhancing Australian culture, they are likely to be more relaxed about higher immigration. Supporters of multiculturalism, for example, want higher levels of immigration than assimilationists (Goot 1993; McAllister 
1993a; Markus et al. 2009), findings consistent with studies from Europe (Sniderman et al. 2004; Citrin and Sides 2006; Ford 2011; Hainmueller and Hangartner 2013).

To capture these socio-cultural dimensions, we propose two hypotheses stemming from the idea that immigrants will be seen as a threat to the dominant white group (H5 and H6) and one hypothesis based on the idea that immigrants are seen as having a stimulating effect on Australian society (H7):

H5: all other things being equal, those who think that immigrants increase crime will be more likely to want to decrease immigrant numbers than those who do not. H6: all other things being equal, those who think that white Australians are advantaged over others in the job market will be more willing to increase the number of immigrants than those who do not.

H7: all other things being equal, those who think that immigrants open Australia to new experiences will be more likely to want to increase the number of immigrants than those who do not.

Another socio-cultural factor that has not been adequately addressed in previous studies is individuals' levels of proximity and contact with immigrants (see Blake 2003). Upon arrival, immigrants do not disperse randomly but instead, they tend to concentrate in areas where accommodation is affordable, jobs are available, shops stock familiar goods, their languages are spoken, relevant community facilities exist, and so on. Examination of the distribution of non-white immigrants in Australia at the electoral district level shows large disparities (see also Markus et al. 2009). In rural divisions such as Braddon in Tasmania, non-white (Asian, African and Middle-Eastern) immigrants form less than two percent of the population. In metropolitan divisions such as Bruce in Victoria, they represent over one-third of the population (calculated from Australian Bureau of Statistics 2013). Such stark differences in the distribution of 'visibly different' immigrants (Perkins 2007) are likely to have an effect on attitudes about immigrants. 
Although living beside non-white immigrants may reduce white Australians' anxieties about them, the growth of non-white Australian numbers in an area may also be seen as a threat, one not experienced by white Australians whose neighbourhoods are white. Following Markus et al. (2009), we suggest that there will be less support for immigration where non-white settlers are more concentrated:

H8: all other things being equal, citizens living in areas with more non-white settlement will be more prone to decrease the number of immigrants than those living in areas with less non-white settlement.

\section{Political factors}

So far, we have focused on the economic and socio-cultural arguments. Our contention is that the political context within which attitudes toward immigration are formed deserves equal attention. Divisive and protracted elite political debates on immigration are likely to have some sway over the public's views about immigrants, including the number of immigrants that should be allowed into a country. This may seem obvious; however, the impact of contentious political events has not previously been considered in studies of the formation of public attitudes toward immigration levels. One of the contributions of this paper is that we test for this relationship.

The issue of asylum seekers attempting to reach Australia by boat-so-called 'boat people'--has provided the core element of Australian elite debates on immigration since 2001. The result of these debates has been to link opposition to asylum seekers arrivals by boat with support for lower overall immigration levels.

To understand the impact of this elite political debate on mass attitudes, it is important to recognise that there is no logically necessary connection between a desire to 'stop the boats' 
and a desire to reduce overall immigration levels. It would be quite consistent, for example, to support higher overall immigration levels but oppose boat arrivals, as the Coalition Government did, or to support lower immigration overall but want people who arrive by boat to be able to remain in Australia. Rather than being the result of unavoidable logic, the connection between 'stopping the boats' and reducing total immigration was developed via three key elements of Coalition rhetoric about asylum seekers over the decade or so before 2013. The first element was the association of boat arrivals with a general 'loss of control' of Australia's borders. The second element was the use of asylum seekers as a synecdoche for immigrants, so that boat people and immigrants became interchangeable in public debate. The third element was the claim that asylum seekers were the cause of socio-economic problems often associated with anti-immigrant sentiment. We explain each of these elements in turn below.

The identification of the arrival of asylum seekers by boat with a general loss of control of Australia's borders began with John Howard's famous election slogan in response to a series of attempts by asylum seekers to reach Australia in the second half of 2001: 'We decide who comes to this country and the circumstances in which they come' (quoted in Marr and Wilkinson 2001: 277). By the 2013 federal election campaign, a well-established Coalition narrative described how the Howard government establishing control of Australia's borders between 2001 and 2007, Labor lost control after 2007, and the Coalition was ready to restore control via its boat turn-back policy (ABC PM 2009; ABC Lateline 2010; ABC Radio 2012; Kelly 2012; Akerman 2013; Albrechtsen 2013; Lane 2013; Coalition 2013: 18)). Labor did not challenge the identification of boat arrivals with a broader threat to Australia's borders, instead pointing to the Coalition's record of boat arrivals under John Howard's government and attempting to find an alternative policy to deal with asylum seekers outside Australia as 
boat arrivals increased under the Rudd and Gillard governments (Jupp 2012; Hawker 2013; McKenzie and Hasmath 2013; Walsh 2014).

The second element — the conflation of immigrants with 'boat people' and immigration policy with asylum seeker policy_was largely complete by the 2013 federal election, when the focus of immigration debate was Tony Abbott's heavily advertised promise to 'stop the boats' by turning them back to Indonesian waters (Abbott 2013; Wroe 2013; Veiszadeh and Salna 2013). The major parties had little else to say about other immigration issues during the campaign. While the Liberal and National parties had released a wide-ranging immigration policy statement at the 2010 election (Coalition 2010), they did not do so in 2013. Instead, they incorporated some general statements about immigration in their omnibus 2013 manifesto (Liberal Party of Australia 2013, 41-42) and focused on asylum seekers in their Operation Sovereign Borders Policy document (Coalition 2013). As Labor and Liberal immigration spokespeople noted during a campaign debate, they concurred on almost all aspects of immigration policy (ABC 2013). These issues slipped off the political agenda, leaving asylum seeker policy the only immigration issue of the campaign (Jupp 2015). Where 'immigration' policy was reported in the news media, the stories almost invariably dealt with asylum seekers (see, for example, Lane 2013; Special Broadcasting Service 2013).

The third element — the claim that asylum seekers were the cause of socio-economic problems--was also prominent during the 2013 campaign. In the most widely publicised example, Liberal candidate Fiona Scott, contesting a seat in western Sydney, blamed asylum seekers for putting pressure on public facilities like hospitals and roads. Speaking about the concerns of voters in her local area, she argued, 'It's a hot topic here ... because our traffic is overcrowded.... [G]o and sit in the emergency department of Nepean Hospital or go and sit on the M4 [highway] and people see 50,000 people come in by boat'. Her statements were defended by Tony Abbott and Liberal immigration shadow minister Scott Morrison, who 
linked asylum seekers to 'population pressures on western Sydney and in places of Melbourne ... [that] put real constraints on the cost of living ... the infrastructure that people can access and the services they can provide' (Australian Broadcasting Corporation 2013). As noted earlier in this paper, socio-economic problems like these are often associated with wider antiimmigrant sentiment.

Leading conservative Australian commentators and Coalition figures have identified an explicit causal relationship between treatment of asylum seeker boats and public attitudes toward immigration in general. The connection was made as early as 2002 , when the free market economist Wolfgang Kasper argued: 'Once people become insecure about border protection ... voters will use the ballot box to stop immigration altogether' (quoted in Goot and Watson 2011, 29). In 2009, The Australian's Paul Kelly described the relationship between government maintenance of border security and public support for immigration as 'the most powerful compact in Australia's history' (cited in McAllister 2011: 223). Other columnists from the same newspaper, including Greg Sheridan (2010) and Janet Albrechtsen (2013), made similar claims. Sheridan found an 'iron law of Australian politics ... If the boats come in large numbers, mainstream support for broader immigration falls. John Howard demonstrated this law by stopping the boats then massively increasing the immigration intake with no notable community opposition' (2010). In a 2013 campaign interview, Liberal spokesperson Scott Morrison asserted: 'I believe in immigration. ... [M]y key objective is to restore confidence in that [immigration] program. To do that we have to restore confidence in our borders' (Special Broadcasting Service 2013). Most recently, Prime Minister Malcolm Turnbull has argued that 'strong borders are not just about security. They are crucial to ensuring social harmony and public support for migration domestically' (quoted in Sheridan 2016).

We do not agree that the relationship between boat arrivals and public sentiment concerning broader immigration levels is an ahistorical 'iron law'; however, given the strong 
identification of asylum seeker arrivals with overall immigration in recent elite political rhetoric, we expect that voters who wanted to stop asylum seeker boats in 2013 would also want immigration numbers reduced.

H9: all other things being equal, those who think that boats should be turned back will be more likely to decrease the number of immigrants than those who do not.

Previous Australian electoral research suggests that party identification will also influence the formation of attitudes on issues such as immigration (McAllister 2011). Since the 'stop the boats' message came from the Liberal and National parties, we expect that voters who identified with the Coalition would have been more likely than other voters to want immigration reduced. Simultaneously, while 67 percent of Coalition identifiers in the 2013 AES agreed or strongly agreed with turning back the boats, the proposal almost evenly divided Labor identifiers: 40 percent agreed or strongly agreed, while 44 percent disagreed or strongly disagreed. We therefore do not expect the relationship between party identification and desired immigration levels to be strong.

H10: all other things being equal, Coalition identifiers will be more likely than other voters to want to reduce the number of immigrants.

\section{Data, variables and estimation}

We use two sorts of data, individual-level and regional-level. The individual-level data comes from the 2013 Australian Election Study (AES), a national post-election survey of a random sample of voters drawn from the electoral roll that has been conducted for each federal election since 1987 (Bean et al. 2014). Our dependent variable is the number of immigrants. The 2013 AES posed this question: 'Do you think the number of immigrants allowed into Australia nowadays should be reduced or increased?'. Respondents had five response categories: increased a lot $(6.2 \%)$, increased a little $(16.8 \%)$, remain about the same as it is $(35.4 \%)$, 
reduced a little (20\%) and reduced a lot $(21.4 \%)$. To simplify the analysis, we have recoded it into three categories: reduce immigration (41.4\%), keep it the same (35.4\%) and increase immigration $(23.1 \%){ }^{1}$

In order to test the hypotheses, we used ten independent variables, as set out in Appendix A. We also include two control variables that address different perceptions of the immigrant experience. These are whether respondents think that there is a lot, a little or hardly any ethnic prejudice in Australia ${ }^{2}$; and their opinions about whether things generally have got better, worse or stayed the same for ethnic minority groups in Australia during the 'past few years' ${ }^{3}$ Finally, we include a set of socioeconomic control variables (see Appendix B for descriptive statistics).

We argued that individuals' attitudes toward immigration levels would not just be driven by personal attributes but by characteristics of the locations in which they live. Rustenbach (2010) has used national boundaries and sub-national regions to get at the impact of location on European attitudes toward immigrants. For Australia, we included data on the eight states and territories and the 150 federal electoral districts. In order to test for variance at the state/territory level, we include each state in a set of dummy variables using the AES data (the two territory sub-samples were too small to warrant testing). We used data taken from the 2011 Australian Census to calculate the total percentage of persons born overseas, as well as the percentage of those born in Asia, Africa and the Middle East, for all 150 federal electoral districts in 2013 (Australian Bureau of Statistics, ABS 2013). The latter percentage is used as a measure for 'non-white' immigrants in an area. The measure is not perfect, since some people born in these country regions will be 'white' and some born in other country regions (for

\footnotetext{
${ }^{1}$ The correlation between the three point and five point scale is 0.91 .

${ }^{2}$ The logic of any possible connection here is unclear. If respondents think there is a lot of prejudice, they will want to increase immigration to overcome it. Alternatively, respondents who do not see much prejudice might think that immigration can safely be increased.

${ }^{3}$ The logic is again not entirely clear but respondents who think that things have become better for ethnic minorities will want to reduce immigration to protect the position of the dominant anglo-celtic group.
} 
example, Europe) will be 'non-white'. Nonetheless, it is a reasonable measure of 'non-white' concentration.

We also include an electoral district level measure of socio-economic advantage and disadvantage developed by the ABS. This measure combines 25 indicators and is initially calculated by the ABS for around 52,000 statistical areas across Australia. The ABS grouped these areas into deciles of relative dis/advantage across Australia. The score that we have used for each electoral division is the median decile for the statistical areas within the division (ABS 2013). Electoral districts, such as Curtin in Western Australia and Warringah in New South Wales, where most collection areas fell in the top decile across the country, were scored 10 . The most disadvantaged electorates, such as Blaxland in New South Wales and Hinkler in Queensland, had medians in the second decile and were scored 2 (no district had medians in the first decile). At the electoral district level, the correlation between the population born in Africa, Asia or the Middle East and relative socio-economic dis/advantage is low (0.35).

Many Australian electoral districts are large. Their average size is 51,361 square kilometres, with a median size of 354 square kilometres (calculated from Australian Electoral Commission 2014). The large size of some districts might be thought to reduce the likelihood of contact between voters and visible immigrant minorities, undermining our efforts to use electoral districts as the spatial unit for testing the relationship between visibility and attitudes to immigrant numbers. Two points can be made in response to such possible concerns. The first is that populations in the largest electoral districts are not spread evenly but are concentrated in towns and villages separated by many kilometers of largely empty land. If non-white immigrants are found in those districts, they will mostly be found in the same population centres as other people. Second, as a robustness check, we tested our models including only those electoral districts of less than 20,000 square kilometres, with no change to the results. 
Given the ordinal nature of the dependent variable, the methodological literature would recommend to use either a generalized ordered logit (Williams 2006), as the parallel-lines assumption is violated; or to rely on a hierarchical logistical ordered model as individuals (almost 3500) are nested within divisions (150) and within states and territories (8). After performing variance component analysis, results showed that almost $96 \%$ of the variance was at the individual level while the division level variance was just $4 \%$, and the state level variance below $0.06 \%$. Given the small variance explained by the states and territories and its uneven distribution, we ran the models nesting individuals within divisions. In order to test the robustness of the hypothesis, we have opted to run both models and present the results simultaneously.

\section{Results}

The results of the generalized ordered logit analysis are in columns 2 and 3 of Table 1 while the multilevel estimation is in column 4. Column 2 coefficients compares voters who want to reduce immigrant numbers with those either wanting to keep the numbers steady or to increase them. Column 3 coefficients compares voters who want to reduce immigrant numbers or to keep the numbers steady with those who want to increase immigrant numbers. In both cases, ssgnificant positive coefficients indicate that respondents with higher scores on the independent variables are more likely than those with lower scores to want to increase immigration, relative to the specified alternative. Significant negative scores show that respondents with higher scores on the independent variable are more likely than those with lower scores to want lower immigration, relative to the specified alternative. Column 4 should be interpreted similarly: negative coefficients show opposition to increasing levels of immigration.

Table 1 about here. 
Overall, the results indicate the importance of all three types of variables - economic, socio-cultural and political. In the Australian case, attitudes toward immigrant numbers are not driven by one of these factors alone but by combinations of each of them. Also importantly, there is barely any difference between the models, highlighting the robustness of the results. We tested the economic explanations through four hypotheses and found significant results for three of them. As expected, the more a respondent agrees that immigrants take jobs away from people who are born in Australia, the more likely it is that she or he will support reducing the number of immigrants and opposes an increase in numbers $(\mathrm{H} 2)$. In stark contrast, the more a respondent agrees that generally immigrants are good for Australia's economy and the more satisfied she is with the present state of the economy, the more likely it is that she or he will want to increase the number of immigrants and oppose a reduction ( $\mathrm{H} 3$ and $\mathrm{H} 4)$. On the other hand, a respondent's household financial situation does not have a significant effect $(\mathrm{H} 1)$. Hence, it seems that in the Australian case, only sociotropic economic factors have an impact on preferences about the number of immigrants, while individualistic stimuli do not.

We found expected support for two of the four socio-cultural explanations: the stronger a respondent's belief that immigrants pose a social threat by increasing the crime rate, the more they will want the numbers of immigrants to be reduced and oppose any increase (H5). Similarly, the more day to day contact respondents have with 'non-white' immigrants because of the areas in which they live, the more they will oppose an increase and want immigration levels reduced $(\mathrm{H} 8)$.

Contextual as well as individual characteristics seem to be important. ${ }^{4}$ Since this finding was based on research not previously attempted in the Australian context, we have explored it further. Table 2 presents the predicted probabilities for the three dependent variable

\footnotetext{
${ }^{4}$ We ran the same model with the inclusion of a variable measuring the percentage of white immigrants in a division. The results for this variable (not reported) were not significant. This further suggests the importance to acceptable levels of immigration of visible differences between the native-born and immigrants, as shown in other countries (eg. Spain, Martinez i Coma and Duval, 2009).
} 
response categories, given different percentages of non-white immigrants in an electoral division, with all other variables set at their means (see Grilli and Rampichini 2012). As the percentage of 'non-white' immigrants in a division increases, so does the percentage of respondents stating that they would like to see the number of immigrants reduced, from 32 percent in divisions with almost no non-white immigrants to 42 percent in those divisions with the largest non-white immigrant populations. The proportion of respondents wanting immigration to increase falls from 15 percent to nine percent. The modal result across all five categories is to keep immigration levels the same, the majority preference among voters in all contexts. Reactions to higher levels of contact with 'non-white' immigrants make voters less willing to countenance more immigration; however, those reactions are not strong enough to make reducing immigration levels the majority preference.

Table 2 about here.

The other two socio-cultural hypotheses were partly supported, since the variables involved only produced significant effects for one of the two available comparisons in the generalized ordered model. In regard to the multiculturalist hypothesis (H7), agreement with the statement that immigrants open up Australia to new ideas and cultures, makes it less likely that respondents will want to reduce immigrant numbers; however, it does not produce support for increasing migrant numbers (compared with keeping them steady or reducing them). Agreement with the proposition that whites are advantaged in job applications does not lessen the likelihood that a voter will want immigration reduced but it does increase the likelihood of that voter supporting increased immigrant numbers (H6). However, following the multilevel estimation, the coefficients are significant.

Results also support our argument about the importance of political context in affecting attitudes to immigration levels (H10). As predicted, the more respondents agreed with Tony Abbott's repeated campaign promise to 'turn back the boats', the more they were likely to want 
to reduce immigration levels (H9). Liberal or National party identification did not have a significant impact, suggesting that Abbott's campaign rhetoric had a broader appeal to voters than those already firmly within the Coalition camp. ${ }^{5}$

Table 3 about here.

Since our argument for the role of the electoral campaign context is one of the most original aspects of this paper, we pursued it further, using the same procedure as for Table 2 but with attitudes to asylum seeker boats as the independent variable. Table 3 shows the expected patterns, with those who strongly agree with turning the boats back having a 55.0 percent probability of wanting to reduce the number of immigrants, compared with a 14.5 percent probability among those who strongly disagree. Nonetheless, opposition to turning back the asylum seeker boats does not produce exactly the reverse effect of support for the policy, with just 28.5 percent of those who strongly disagree wanting to increase immigration levels. Among respondents who are neutral or opposed to the Coalition's boats policy, the majority preference (between 54.2 and 57.6 percent) is for immigration to be kept at current levels. Agreement with the boats policy erodes that consensus, with the median voter among those strongly supporting the policy wanting to reduce immigrant numbers.

Of the few individual-level control variables that showed significant and consistent effects, working class self-identification and a belief that things had become worse for ethnic minority groups in Australia both produced a desire for lower immigration levels, while more frequent religious attendance had the opposite effect. At the regional level, contextual socioeconomic (dis)advantage had no significant impact, while respondents from South Australia-and, to a lesser degree, Queensland--tended to support higher immigration levels than respondents from other states.

\footnotetext{
${ }^{5}$ In two further models (not reported) we included interaction variables using party identification and stance on turning back asylum seeker boats. Neither of these models produced additional significant coefficients or affected the results for the variables reported here.
} 


\section{Conclusion}

Australia represents an important case for investigating attitudes to immigration levels because it combines a longstanding immigration program, comparatively high immigration levels and a diverse mix of immigrant source countries. The results of our research show that in many respects the attitudes of the Australian public are very similar to those of publics in other countries. The sociotropic economic and socio-cultural factors found to have an influence in other countries also had an effect on Australian immigration preferences.

More originally from a comparative perspective, we also demonstrate the importance of proximity where immigrants and the native-born are visibly different: citizens who lived in electoral districts with higher percentages of non-white immigrants were more likely to want to reduce immigrant numbers than those who lived in districts with lower percentages. Future testing of more fine-grained neighbourhood effects would provide stronger evidence about the importance of proximity on attitudes towards immigrants than was possible here.

Finally, we have explored the neglected idea that political factors, such as the specific dynamics of election campaigns, are an important third type of determinant of views on immigration. Most studies on public attitudes to immigration levels keep politics firmly in the background. Instead, they focus on economic and socio-cultural factors that are assumed to drive attitudes independently of political contexts. The assumption is that, for example, an unskilled worker does not need a politician to tell her that the arrival of unskilled workers from other countries will put pressure on her job, or that groups of immigrants who look different are to be treated with suspicion. Where political factors are included, they tend to be treated as relatively fixed components of individual identities, such as their broad left-right ideological leanings or general political engagement (Rustenbach 2010). The finding from this study that popular agreement with the Coalition's oft-repeated promise to 'turn back the boats' is strongly 
correlated with support for reducing immigration levels suggests that more fluid political dynamics also play a part in mobilising attitudes toward immigration policies. The impact of the Coalition's boat policy on Australian opinion makes a compelling case for systematically incorporating similar political factors into future explanations of public preferences about immigrant numbers. 


\section{References}

Abbott, Tony. 2013. "Address to the 2013 Federal Coalition Campaign Launch." August 25. Accessed October 23 2104. http://www.liberal.org.au/latest-news/2013/08/25/tonyabbott-address-2013-federal-coalition-campaign-launch

ABC PM. 2009. "Asylum Seeker Boats Revive Political Debate." October 13. http://www.abc.net.au/radio/programs/pm/asylum-seeker-boats-revive-politicaldebate/1103468

ABC Lateline. 2010. "Rudd Under Fire Over Record Boat Arrivals." March 29. http://www.abc.net.au/news/2010-03-29/rudd-under-fire-over-record-boat$\underline{\operatorname{arrivals} / 385538}$

ABC Radio Australia. 2012. "Warning on Australian Immigration Border Control." January 6. http://www.radioaustralia.net.au/international/radio/onairhighlights/warning-onaustralian-immigration-border-control

ABC PM. 2013. "Scott Morrison Criticises Govt for 'Dumping' Refugees." September 3. http://www.abc.net.au/pm/content/2013/s3840196.htm

Akerman, Piers. 2013. “Labor's Waking up to a Bitter Pill Hangover.” Sunday Telegraph June 9. http://www.dailytelegraph.com.au/news/opinion/labors-leadership-debacle-hasparty-waking-up-to-a-bitter-pill-hangover/newsstory/78fe4e3403f413739e087bc4cbabd245

Albrechtsen, Janet. 2013. "Get Ready for Leftist Hysteria if Abbott Wins the Election." The Australian 28 August: 12. http://www.theaustralian.com.au/opinion/columnists/getready-for-leftist-hysteria-if-abbott-wins-the-election/newsstory/77083bc01ae6835d820157772184f3c0

Australian Bureau of Statistics [ABS]. 2013. "2012 Commonwealth Electoral Divisions." Accessed $17 \quad$ July 2014. http://www.abs.gov.au/websitedbs/censushome.nsf/home/tablebuilderdata2012ced?op endocument\&navpos $=240$

Australian Electoral Commission. 2014. "Current Federal Electoral Divisions." Accessed 21 January 2015. http://www.aec.gov.au/profiles/

Bean, Clive, Ian McAllister, Juliet Pietsch, and Rachel K. Gibson. 2014. Australian Election Study, 2013. [Computer file]. Canberra: Australian Data Archive, The Australian National University.

Betts, Katharine. 2010. "Attitudes to Immigration and Population Growth in Australia 1954 to 2010: An Overview." People and Place 18(3): 32-51.

Betts, Katharine. 2002. "Immigration and Public Opinion: Understanding the Shift." People and Place 10(4): 24-37.

Blake, Donald E. 2003. "Environmental Determinants of Racial Attitudes Among White Canadians." Canadian Journal of Political Science 36: 491-509.

Citrin, Jack, Donald Green, Christopher Muste, and Cara Wong. 1997. "Public Opinion Toward Immigration Reform: The Role of Economic Motivations." Journal of Politics 59: 858-81. 
Citrin, Jack, Beth Reingold, and Donald Green. 1990. "American Identity and the Politics of Ethnic Change." Journal of Politics 52: 1124-54.

Coalition. 2010. The Coalition's Policy for Population and Immigration. Accessed 26 November 2014. http://www.nationals.org.au/Portals/0/2010/policy/100725-LPAPopulation-and-Immigration-Policy.pdf

Coalition. 2013. Operation Sovereign Borders Policy. Barton: Liberal and National Parties.

Espenshade, Thomas J. and Charles A. Calhoun. 1993. "An Analysis of Public Opinion toward Undocumented Immigration." Population Research and Policy Review 12: 189-224.

Facchini, Giovanni and Anna Maria Mayda. 2006. "Individual Attitudes towards Immigrants: Welfare-State Determinants Across Countries.” IZA Discussion Paper No. 2127.

Ford, Robert. 2011. "Acceptable and Unacceptable Immigrants: How Opposition to Immigration in Britain is Affected by Migrants' Region of Origin." Journal of Ethnic and Migration Studies 37: 1017-37.

Goot, Murray. 2000. “More 'Relaxed and Comfortable': Public Opinion on Immigration Under Howard." People and Place 8: 46-60.

Goot, Murray. 1993. "Multiculturalists, Monoculturalists and the Many in Between: Attitudes to Cultural Diversity and Their Correlates." Australian and New Zealand Journal of Sociology 29: 226-53.

Goot, Murray and Ian Watson. 2011. Population, Immigration and Asylum Seekers: Patterns in Australian Public Opinion. Canberra: Parliament of Australia, Department of Parliamentary Services.

Goot, Murray and Ian Watson. 2010. "Nativism as Citizenship: Immigration, Economic Hardship and the Politics of the Right." In From Migrant to Citizen: Testing Language, Testing Culture, edited by C. Slade and M. Möllering, 217-35. Houndmills: Palgrave Macmillan.

Goot, Murray and Ian Watson. 2005. "Immigration, Multiculturalism and National Identity". In Australian Social Attitudes: The First Report, edited by Shaun Wilson, Rachel Gibson, David Denemark and Mark Western, 182-203, 263-67. Sydney: University of New South Wales Press.

Goot, Murray and Ian Watson. 2001. "One Nation's Electoral Support: Where Does it Come From, What Makes it Different and How Does it Fit?" Australian Journal of Politics and History 47: 159-191.

Grilli, Leonardo and Carla Rampichini. 2012. "Multilevel Models for Ordinal Data." In Modern Analysis of Customer Surveys: with Applications using $R$, edited by Ron Kennett and Silvia Salini, 391-412. New York: Wiley.

Hainmueller, Jens and Dominik Hangartner. 2013. "Who gets a Swiss Passport? A Natural Experiment in Immigrant Discrimination." American Political Science Review 107: $159-87$.

Hainmueller, Jens and Michael Hiscox. 2010. "Attitudes toward Highly Skilled and LowSkilled Immigration: Evidence from a Survey Experiment." American Political Science Review 104: 61-84. 
Hawker, Bruce. 2013. The Rudd Rebellion: The Campaign to Save Labor. Melbourne: Melbourne University Press.

Jupp, James. 2015. "Ethnic Voting and Asylum Issues.” In Abbott's Gambit: The 2013 Federal Election, edited by Carol Johnson, John Wanna and Hsu-Ann Lee, 323-40. Canberra: ANU Press.

Jupp, James. 2012. "Immigration Issues in the 2010 Election." In Julia 2010, edited by Marian Simms and John Wanna, 267-78. Canberra: ANU E Press.

Jupp, James. 2007. From White Australia to Woomera: The Story of Australian Immigration. Cambridge: Cambridge University Press, second edition.

Jupp, James. 1995. "From 'White Australia' to 'Part of Asia': Recent Shifts in Australian Immigration Policy Towards the Region." International Migration Review 29: 207-28.

Jupp, James. 1966. Arrivals and Departures. Melbourne: Cheshire.

Kelly, Paul. 2012 “I'll Turn Back Every Boat, Says Tony Abbott.” The Australian. January 21. http://www.theaustralian.com.au/national-affairs/ill-turn-back-every-boat-says-tonyabbott/news-story/ac85b31a0cf49f6258198c7866a2d2dd

Landis, Dan and Jerry Boucher. 1987. "Themes and Models of Conflict." In Ethnic Conflict: International Perspectives, edited by Jerry Boucher, Dan Landis and Karen Clark, 1732. Beverly Hills: Sage.

Lane, Sabra. 2013. "Abbott Resurrects Howard-Era Immigration Policy." The World Today, ABC Radio, $16 \quad$ August. http://www.abc.net.au/worldtoday/content/2013/s3827139.htm

Lee, Siu-yau, Lina Vyas, and Kee-lee Chou. 2016. "Welcoming Immigrants with Similar Occupational Interests: Experimental Survey Evidence from Hong Kong." Political Studies 65(2) 391-412.

Liberal Party of Australia. 2013. Our Plan: Real Solutions for All Australians. Barton: Liberal Party of Australia.

McAllister, Ian. 2011. The Australian Voter: 50 Years of Change. Sydney: UNSW Press.

McAllister, Ian. 1993a. "Public Opinion, Multiculturalism, and Political Behaviour in Australia". In Multicultural Citizens: The Philosophy and Politics of Identity, edited by Chandran Kukathas, 51-60. Sydney: Centre for Independent Studies.

McAllister, Ian. 1993b. Immigration, Bi-Partisanship and Public Opinion. In The Politics of Australian Immigration, edited by James Jupp and Marie Kabala, 161-78. Canberra: Australian Government Publishing Service.

McKenzie, Jaffa and Reza Hasmath. 2013. "Deterring the 'Boat People': Explaining the Australian Government's People Swap Response to Asylum Seekers." Australian Journal of Political Science 48: 417-30.

Markus, Andrew. 2014. Attitudes to Immigration and Cultural Diversity in Australia. Journal of Sociology 50(1): 10-22.

Markus, Andrew. 2016. Mapping Social Cohesion: The Scanlon Foundation Surveys 2016. Caulfield East: Monash University. 
Markus, Andrew and Arunchalam Dharmalingam. 2007. Mapping Social Cohesion: The Scanlon Foundation Surveys. Caulfield East: Monash University.

Markus, Andrew, James Jupp, and Peter McDonald. 2009. Australia's Immigration Revolution. Crows Nest: Allen and Unwin.

Marr, David and Marian Wilkinson. 2003. Dark Victory. Crows Nest: Allen and Unwin.

Martinez i Coma, Ferran and Robert Duval-Hernandez. 2009. Hostility Toward Immigration in Spain. IZA discussion papers, No. 4109.

Mayda, Anna Maria. 2006. "Who is Against Immigration? A Cross-Country Investigation of Individual Attitudes toward Immigrants." The Review of Economics and Statistics 88: 510-30.

O'Rourke, Kevin, and Richard Sinnott. 2006. "The Determinants of Individual Attitudes Towards Immigration." European Journal of Political Economy 22: 838-61.

Perkins, Maureen (ed.). 2007. Visibly Different: Face, Place and Race in Australia. Bern: Peter Lang.

Ratcliff, Shaun. 2014. "Studying Voter Behaviour and Policy Outcomes: The Case of Immigration in Australia." Polimetrics 1: 5-9.

Rustenbach, Elisa. 2010. "Source of Negative Attitudes toward Immigrants in Europe: A MultiLevel Analysis." International Migration Review 44: 53-77.

Sheridan, Greg. 2016. "Malcolm Turnbull's Strong Words on Border Control Appreciated by All." The Australian 24. http://www.theaustralian.com.au/opinion/columnists/greg-sheridan/malcolmturnbulls-strong-words-on-border-control-appreciated-by-all/newsstory/783a7ca1db709fab16fd85d2d91f887f

Sheridan, Greg. 2010. "A National Disgrace and Frolic All of Her Own Making”. The Australian July 22: 7.

Sides, John and Jack Citrin. 2007. "European Opinion about Immigration: The Role of Identities, Interests and Information.” British Journal of Political Science 37: 477-504.

Smith, Rodney. 2001. Australian Political Culture. Sydney: Longman.

Sniderman, Paul, Louk Hagendoorn, and Markus Prior. 2004. "Predisposing Factors and Situational Triggers: Exclusionary Reactions to Immigrant Minorities." American Political Science Review 98: 35-49.

Special Broadcasting Service. 2013. "Major Parties Avoid Detailed Immigration Policy Debate." September 3. http://www.sbs.com.au/news/article/2013/09/03/major-partiesavoid-detailed-immigration-policy-debate

Veiszadeh, Ehssan and Karlis Salna. 2013. “Abbott Defends Asylum Tow-Back Plan.” The Daily Telegraph April 23. http://www.news.com.au/national/breaking-news/abbott-arisk-to-indon-relations-govt/news-story/1dc2f90c03750986d0fcb0d3e626117d

Walsh, Mary. 2014. "The Gillard Government, the Coalition and Asylum Seekers". In The Gillard Governments, edited by Chris Aulich, 125-40. Melbourne: Melbourne University Press. 
Wilkes, Rima, Neil Guppy, and Lily Farris. 2008. "No Thanks, We're Full': Individual Characteristics, National Context, and Changing Attitudes Toward Immigration." International Migration Review 42: 302-29.

Williams, Richard. 2006. "Generalized Ordered Logit/Partial Proportional Odds Models for Ordinal Dependent Variables.” The Stata Journal 6: 58-82.

Wroe, David. 2013. "We Won’t Help Abbott Turn Back Boats: Indonesia." The Age June 1. http://www.smh.com.au/federal-politics/political-news/we-wont-help-abbott-turnback-boats-indonesia-20130531-2nhgx.html?deviceType=text 
Table 1. Effects of individual and contextual characteristics on voter attitudes to immigrant numbers: generalized ordered logit analysis..

\begin{tabular}{|c|c|c|c|}
\hline & $\begin{array}{l}\text { Keep the } \\
\text { same or } \\
\text { increase vs } \\
\text { reduce }\end{array}$ & $\begin{array}{l}\text { Increase vs } \\
\text { reduce or } \\
\text { keep the } \\
\text { same }\end{array}$ & $\begin{array}{l}\text { Division } \\
\text { level } \\
\text { Multilevel }\end{array}$ \\
\hline Resources (H1) & $\begin{array}{l}-0.014 \\
(0.050)\end{array}$ & $\begin{array}{l}0.019 \\
(0.056)\end{array}$ & $\begin{array}{l}-0.003 \\
(0.041)\end{array}$ \\
\hline Job threat $(\mathrm{H} 2)$ & $\begin{array}{l}\mathbf{- 0 . 4 9 4 * * *} \\
(0.052)\end{array}$ & $\begin{array}{l}-\mathbf{0 . 2 3 7} * * * \\
(0.062)\end{array}$ & $\begin{array}{l}-\mathbf{0 . 4 0 7} * * * \\
(0.043)\end{array}$ \\
\hline Optimism (H3) & $\begin{array}{l}\mathbf{0 . 0 5 6} * * * * \\
(0.021)\end{array}$ & $\begin{array}{l}\text { 0.049* } \\
(0.025)\end{array}$ & $\begin{array}{l}\mathbf{0 . 0 5 5}^{* * * *} \\
(0.018)\end{array}$ \\
\hline Res publica (H4) & $\begin{array}{l}\mathbf{0 . 7 0 2 * * *} \\
(0.070)\end{array}$ & $\begin{array}{l}\text { 1.033*** } \\
(0.103)\end{array}$ & $\begin{array}{l}\mathbf{0 . 7 8 5 * * *} \\
(0.061)\end{array}$ \\
\hline Crime (H5) & $\begin{array}{l}\mathbf{- 0 . 4 0 1 * * *} \\
(0.057)\end{array}$ & $\begin{array}{l}-\mathbf{0 . 2 4 3} * * * \\
(0.064)\end{array}$ & $\begin{array}{l}-\mathbf{0 . 3 2 6} * * * * \\
(0.045)\end{array}$ \\
\hline White jobs (H6) & $\begin{array}{l}\mathbf{0 . 0 5 7} \\
(0.044)\end{array}$ & $\begin{array}{l}\mathbf{0 . 1 4 0 * * *} \\
(0.047)\end{array}$ & $\begin{array}{l}\mathbf{0 . 0 9 6 * * *} \\
(0.034)\end{array}$ \\
\hline Multiculturalism (H7) & $\begin{array}{l}\mathbf{0 . 1 7 1 * * *} \\
(0.066)\end{array}$ & $\begin{array}{l}0.090 \\
(0.083)\end{array}$ & $\begin{array}{l}\mathbf{0 . 1 4 0} \text { *** } \\
(0.056)\end{array}$ \\
\hline Proximity (H8) & $\begin{array}{l}-\mathbf{- 0 . 0 1 1 *} \\
(0.006)\end{array}$ & $\begin{array}{l}-\mathbf{0 . 0 1 5 * *} \\
(0.007)\end{array}$ & $\begin{array}{l}-\mathbf{- 0 . 0 1 2} * * \\
(0.005)\end{array}$ \\
\hline Boats (H9) & $\begin{array}{l}\mathbf{- 0 . 4 9 4 * * *} \\
(0.044)\end{array}$ & $\begin{array}{l}-\mathbf{0 . 4 2 9} * * * \\
(0.048)\end{array}$ & $\begin{array}{l}-\mathbf{- 0 . 4 5 8} * * * \\
(0.033)\end{array}$ \\
\hline Labor identification (H10) & $\begin{array}{l}0.172 \\
(0.127)\end{array}$ & $\begin{array}{l}0.064 \\
(0.128)\end{array}$ & $\begin{array}{l}0.098 \\
(0.101)\end{array}$ \\
\hline Coalition identification (H10) & $\begin{array}{l}0.161 \\
(0.123)\end{array}$ & $\begin{array}{l}0.128 \\
(0.138)\end{array}$ & $\begin{array}{l}0.135 \\
(0.103)\end{array}$ \\
\hline Ethnic minorities & $\begin{array}{l}-\mathbf{0 . 1 5 9} * * * \\
(0.049)\end{array}$ & $\begin{array}{l}-\mathbf{0 . 1 2 5} * * \\
(0.059)\end{array}$ & $\begin{array}{l}-\mathbf{0 . 1 4 2} * * * \\
(0.041)\end{array}$ \\
\hline Ethnic prejudice & $\begin{array}{l}0.090 \\
(0.081)\end{array}$ & $\begin{array}{l}\mathbf{0 . 2 2 3} * * \\
(0.091)\end{array}$ & $\begin{array}{l}\text { 0.124** } \\
(0.066)\end{array}$ \\
\hline Gender & $\begin{array}{l}\mathbf{- 0 . 2 9 7 * * *} \\
(0.095)\end{array}$ & $\begin{array}{l}0.026 \\
(0.104)\end{array}$ & $\begin{array}{l}-\mathbf{0 . 1 5 5}{ }^{* *} \\
(0.077)\end{array}$ \\
\hline Age & $\begin{array}{l}0.00500 \\
(0.003)\end{array}$ & $\begin{array}{l}-\mathbf{- 0 . 0 0 6 *} \\
(0.003)\end{array}$ & $\begin{array}{l}0.000 \\
(0.002)\end{array}$ \\
\hline Relationship status & $\begin{array}{l}-0.086 \\
(0.146)\end{array}$ & $\begin{array}{l}0.048 \\
(0.152)\end{array}$ & $\begin{array}{l}-0.001 \\
(0.115)\end{array}$ \\
\hline Class identification & $\begin{array}{l}-\mathbf{- 0 . 1 8 0 *} \\
(0.097)\end{array}$ & $\begin{array}{l}-\mathbf{0 . 2 5 2} * * \\
(0.114)\end{array}$ & $\begin{array}{l}-\mathbf{0 . 1 9 8} * * \\
(0.082)\end{array}$ \\
\hline Religious attendance & $\begin{array}{l}\text { 0.113* } \\
(0.061)\end{array}$ & $\begin{array}{l}\mathbf{0 . 1 8 7 * * * *} \\
(0.063)\end{array}$ & $\begin{array}{l}\mathbf{0 . 1 5 1} * * * \\
(0.049)\end{array}$ \\
\hline Location & $\begin{array}{l}0.186 \\
(0.117)\end{array}$ & $\begin{array}{l}0.210 \\
(0.133)\end{array}$ & $\begin{array}{l}\text { 0.187** } \\
(0.096)\end{array}$ \\
\hline Education 1 & $\begin{array}{l}\mathbf{0 . 2 6 5} \text { ** } \\
(0.116)\end{array}$ & $\begin{array}{l}0.124 \\
(0.124)\end{array}$ & $\begin{array}{l}\mathbf{0 . 2 0 7 * *} \\
(0.094)\end{array}$ \\
\hline Education2 & $\begin{array}{l}\mathbf{0 . 2 4 6 * *} \\
(0.111)\end{array}$ & $\begin{array}{l}0.035 \\
(0.139)\end{array}$ & $\begin{array}{l}\mathbf{0 . 1 6 7 *} \\
(0.094)\end{array}$ \\
\hline Employment status & $\begin{array}{l}-0.022 \\
(0.101)\end{array}$ & $\begin{array}{l}-0.062 \\
(0.111)\end{array}$ & $\begin{array}{l}-0.047 \\
(0.083)\end{array}$ \\
\hline Socio-economic advantage of electoral district & $\begin{array}{l}0.016 \\
(0.026)\end{array}$ & $\begin{array}{l}0.043 \\
(0.028)\end{array}$ & $\begin{array}{l}0.028 \\
(0.021)\end{array}$ \\
\hline State/Territory: Victoria & $\begin{array}{l}-0.125 \\
(0.120)\end{array}$ & $\begin{array}{l}0.106 \\
(0.131)\end{array}$ & $\begin{array}{l}-0.016 \\
(0.099)\end{array}$ \\
\hline State/Territory: Queensland & $\begin{array}{l}\mathbf{0 . 3 3 1} * * \\
(0.131)\end{array}$ & $\begin{array}{l}0.158 \\
(0.151)\end{array}$ & $\begin{array}{l}\mathbf{0 . 2 5 9 * *} \\
(0.108)\end{array}$ \\
\hline State/Territory: South Australia & $\begin{array}{l}\mathbf{0 . 3 3 7 * *} \\
(0.168)\end{array}$ & $\begin{array}{l}\mathbf{0 . 5 2 1} * * * \\
(0.182)\end{array}$ & $\begin{array}{l}\mathbf{0 . 4 1 3} * * * \\
(0.141)\end{array}$ \\
\hline State/Territory: Western Australia & $\begin{array}{l}0.037 \\
(0.172) \\
\end{array}$ & $\begin{array}{l}0.083 \\
(0.194) \\
\end{array}$ & $\begin{array}{l}0.036 \\
(0.138) \\
\end{array}$ \\
\hline
\end{tabular}


State/Territory: Tasmania

State/Territory: Northern Territory

State/Territory: Australian Capital Territory

Constant

Cut 1

Cut 2

Observations

Number of groups

Pseudo $\mathrm{R}^{2}$

$* \mathrm{p}<.1 ; * * \mathrm{p}<.05 ; * * * \mathrm{p}<.01$

$\begin{array}{lll}0.131 & 0.264 & 0.190 \\ (0.254) & (0.255) & (0.202) \\ -0.0942 & 0.890 & 0.386 \\ (0.503) & (0.548) & (0.435) \\ 0.0258 & -0.234 & -0.149 \\ (0.507) & (0.363) & (0.307) \\ \mathbf{1 . 1 6 9 *} & \mathbf{- 4 . 0 8 9 * * *} & \\ (0.601) & (0.734) & \\ & & -0.181 \\ & & (0.483) \\ & & \mathbf{2 . 3 7 2 * * *} \\ & & (0.484)\end{array}$

$\begin{array}{cc}3,483 & 3,483 \\ & 1503\end{array}$

0.298 
Table 2. Predicted probabilities of attitudes to immigration levels as percentage of "non-white" immigrants in area increases.

"Non-white" immigrants as a percentage of the population in an

Immigration numbers electoral division.

should be:

$1 \% \quad 10 \%$

Reduced

.320

.342

Kept the same

.533

.342

.147

.130

518

$20 \% \quad 30 \%$

$30 \%$
.394
.506

.099

.492

Increased

.114

.086


Table 3. Predicted probabilities of attitudes to immigration levels as support for turning back asylum seeker boats increases.

All boats carrying asylum seekers should be turned back

Immigration numbers Strongly Disagree Neither disagree agree nor Agree Strongly should be: disagree

\begin{tabular}{llllll}
\hline Reduced & .145 & .218 & .313 & .428 & .550 \\
\hline Kept the same & .570 & .576 & .542 & .473 & .383 \\
\hline Increased & .285 & .206 & .144 & .099 & .067 \\
\hline
\end{tabular}




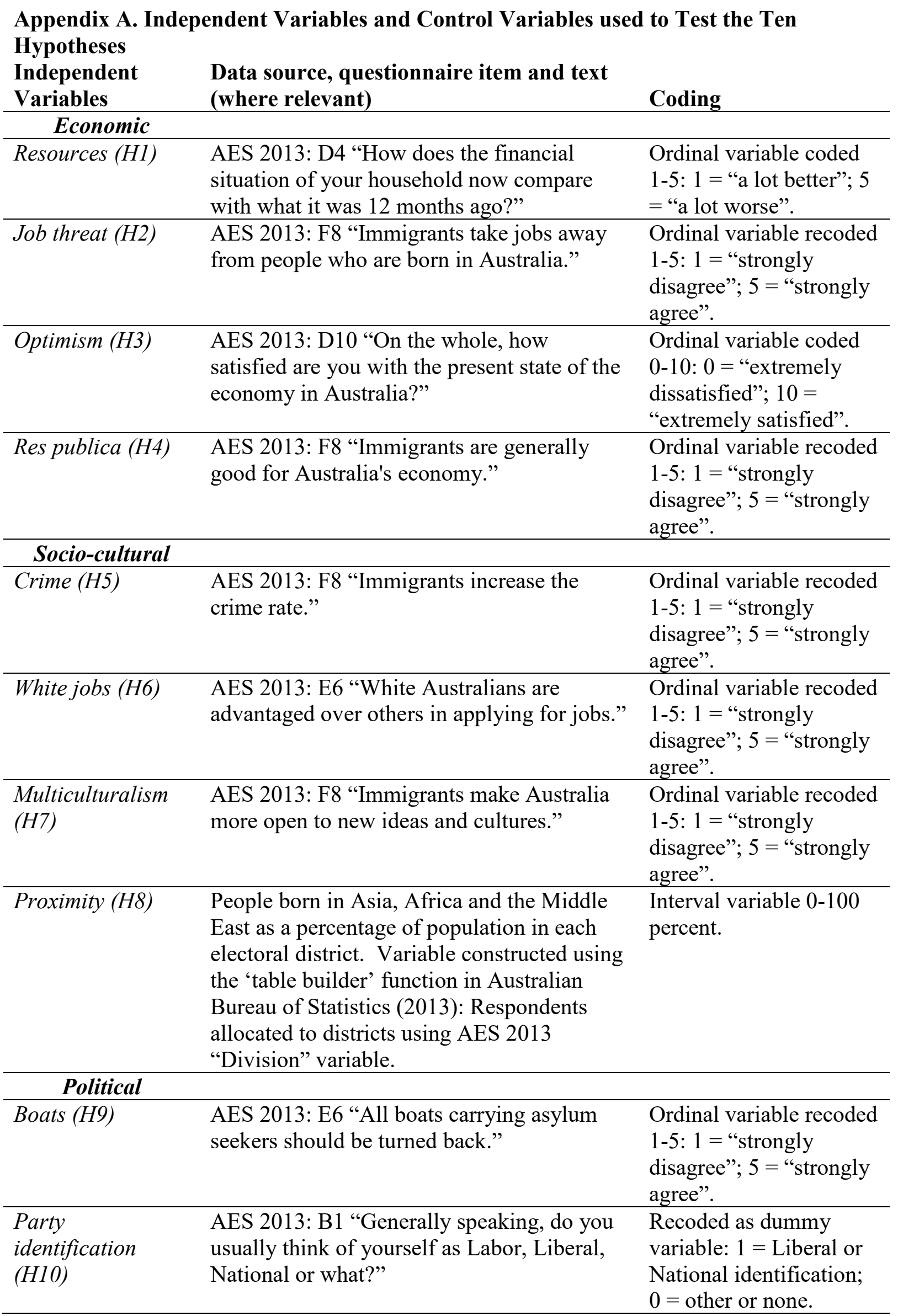




\begin{tabular}{|c|c|c|}
\hline $\begin{array}{l}\text { Control } \\
\text { Variables }\end{array}$ & & $\begin{array}{l}\text { Ordinal variable recoded } \\
1-5: 1=\text { "strongly } \\
\text { disagree"; } 5=\text { "strongly } \\
\text { agree". }\end{array}$ \\
\hline $\begin{array}{l}\text { Labor } \\
\text { identification }\end{array}$ & $\begin{array}{l}\text { AES 2013: B1 "Generally speaking, do you } \\
\text { usually think of yourself as Labor, Liberal, } \\
\text { National or what?" }\end{array}$ & $\begin{array}{l}\text { Recoded as dummy } \\
\text { variable: } 1=\text { Labor } \\
\text { identification; } 0=\text { other } \\
\text { or none. }\end{array}$ \\
\hline Ethnic minorities & $\begin{array}{l}\text { AES 2013: E8 "Thinking about the past few } \\
\text { years, have things generally got better or } \\
\text { worse for ethnic minority groups in } \\
\text { Australia, or have things stayed much the } \\
\text { same?" }\end{array}$ & $\begin{array}{l}\text { Ordinal variable recoded } \\
\text { 1-5: } 1=\text { "a lot worse"; } 5 \\
=\text { "a lot better". }\end{array}$ \\
\hline Ethnic prejudice & $\begin{array}{l}\text { AES 2013: E9 "Do you think there is a lot of } \\
\text { ethnic prejudice in Australia nowadays, a } \\
\text { little or hardly any?" }\end{array}$ & $\begin{array}{l}\text { Ordinal variable recoded } \\
\text { 1-3: } 1=\text { "hardly any"; } 5 \\
=\text { "a lot". }\end{array}$ \\
\hline Gender & AES 2013: H1 "Are you male or female?" & $\begin{array}{l}\text { Recoded as dummy } \\
\text { variable: } 1=\text { female; } 0= \\
\text { male. }\end{array}$ \\
\hline Age & $\begin{array}{l}\text { AES 2013: H2 "In what year were you } \\
\text { born?" }\end{array}$ & $\begin{array}{l}\text { Continuous variable } \\
\text { recoded from } 18-103 \\
\text { years. }\end{array}$ \\
\hline $\begin{array}{l}\text { Class } \\
\text { identification }\end{array}$ & $\begin{array}{l}\text { AES 2013: H13 "Which social class would } \\
\text { you say you belong to?" }\end{array}$ & $\begin{array}{l}\text { Recoded as dummy } \\
\text { variable: } 1=\text { working } \\
\text { class; } 0=\text { other or none. }\end{array}$ \\
\hline $\begin{array}{l}\text { Religious } \\
\text { attendance }\end{array}$ & $\begin{array}{l}\text { AES 2013: H7 "Apart from weddings, } \\
\text { funerals and baptisms, about how often do } \\
\text { you attend religious services?" }\end{array}$ & $\begin{array}{l}\text { Ordinal variable recoded } \\
1=\text { less than once a } \\
\text { year; } 2=\text { several times a } \\
\text { a year; } 3=\text { at least once } \\
\text { a month. }\end{array}$ \\
\hline Relationship status & $\begin{array}{l}\text { AES 2013: H8 "What is your current marital } \\
\text { status?" }\end{array}$ & $\begin{array}{l}\text { Recoded as dummy } \\
\text { variable: } 1=\text { single; } 0= \\
\text { other. }\end{array}$ \\
\hline Location & $\begin{array}{l}\text { AES 2013: H14 "Would you say you now } \\
\text { live in..." }\end{array}$ & $\begin{array}{l}\text { Recoded as dummy } \\
\text { variable: } 1=\text { large town } \\
\text { or city; } 0=\text { other. }\end{array}$ \\
\hline $\begin{array}{l}\text { Education1 and } \\
\text { Education2 }\end{array}$ & $\begin{array}{l}\text { AES 2013: G3 "Have you obtained a trade } \\
\text { qualification, a degree or a diploma, or any } \\
\text { other qualification since leaving school? } \\
\text { What is your highest qualification?" }\end{array}$ & $\begin{array}{l}\text { Recoded as two dummy } \\
\text { variables: } 1=\text { school } \\
\text { only; } 0=\text { post-school } \\
\text { qualification; and } 1= \\
\text { university qualification; } \\
0=\text { other. }\end{array}$ \\
\hline Employment status & $\begin{array}{l}\text { AES 2013: G4 "Last week, what were you } \\
\text { mainly doing?" }\end{array}$ & $\begin{array}{l}\text { Recoded as dummy } \\
\text { variable: } 1=\text { full time } \\
\text { paid work; } 0=\text { other. }\end{array}$ \\
\hline $\begin{array}{l}\text { Socio-Economic } \\
\text { Advantage of } \\
\text { Electoral District. }\end{array}$ & $\begin{array}{l}\text { Australian Bureau of Statistics (2013): } \\
\text { Socio-economic (dis)advantage scores for } \\
\text { each electoral district. Respondents } \\
\text { allocated to districts using AES } 2013 \\
\text { "Division" variable. }\end{array}$ & $\begin{array}{l}\text { Interval variable: } 1= \\
\text { most disadvantaged; } 10 \\
=\text { most advantaged. }\end{array}$ \\
\hline
\end{tabular}


Appendix B. Descriptive statistics

\begin{tabular}{|c|c|c|c|c|c|}
\hline Variable & $\mathbf{N}$ & Mean & Std.Dev. & Min & Max \\
\hline Number of immigrants & 3483 & 1.83 & .78 & 1 & 3 \\
\hline \multicolumn{6}{|l|}{ Variables of interest } \\
\hline \multicolumn{6}{|l|}{ Economic } \\
\hline Resources (H1) & 3483 & 3.27 & .96 & 1 & 5 \\
\hline Job threat $(\mathrm{H} 2)$ & 3483 & 2.95 & 1.13 & 1 & 5 \\
\hline Optimism (H3) & 3483 & 4.91 & 2.33 & 0 & 10 \\
\hline Res publica (H4) & 3483 & 3.49 & .9 & 1 & 5 \\
\hline \multicolumn{6}{|l|}{ Socio-cultural } \\
\hline Crime (H5) & 3483 & 3.12 & 1.13 & 1 & 5 \\
\hline White jobs (H6) & 3483 & 2.83 & 1.14 & 1 & 5 \\
\hline Multiculturalism (H7) & 3483 & 3.81 & .91 & 1 & 5 \\
\hline Proximity (H8) & 3483 & 9.8 & 8.84 & 1 & 38 \\
\hline \multicolumn{6}{|l|}{ Political } \\
\hline Boats (H9) & 3483 & 3.28 & 1.45 & 1 & 5 \\
\hline Labor identification (H10) & 3483 & .35 & .47 & 0 & 1 \\
\hline Coalition identification (H10) & 3483 & .41 & .49 & 0 & 1 \\
\hline \multicolumn{6}{|l|}{ Controls } \\
\hline Ethnic minorities & 3483 & 3.54 & .97 & 1 & 5 \\
\hline Ethnic prejudice & 3483 & 2.25 & .59 & 1 & 3 \\
\hline Gender & 3483 & .51 & .49 & 0 & 1 \\
\hline Age & 3483 & 53 & 16.6 & 14 & 103 \\
\hline Working class & 3483 & .37 & .48 & 0 & 1 \\
\hline Religious Frequency & 3483 & 1.51 & .75 & 1 & 3 \\
\hline Location & 3483 & .705 & .45 & 0 & 1 \\
\hline Single & 3483 & .16 & .37 & 0 & 1 \\
\hline Univ degree & 3483 & .35 & .47 & 0 & 1 \\
\hline No qualif & 3483 & .28 & .45 & 0 & 1 \\
\hline Employment status & 3483 & .39 & .48 & 0 & 1 \\
\hline $\begin{array}{l}\text { Socio-economic adv of elec } \\
\text { district }\end{array}$ & 3483 & 5.54 & 2.04 & 2 & 10 \\
\hline VIC & 3483 & .24 & .43 & 0 & 1 \\
\hline QLD & 3483 & .19 & .39 & 0 & 1 \\
\hline SA & 3483 & .09 & .28 & 0 & 1 \\
\hline WA & 3483 & .09 & .29 & 0 & 1 \\
\hline TAS & 3483 & .03 & .19 & 0 & 1 \\
\hline NT & 3483 & .007 & .08 & 0 & 1 \\
\hline ACT & 3483 & .01 & .12 & 0 & 1 \\
\hline
\end{tabular}

